\title{
Fukuyama's End Of History Thesis: Are Western Marketing Theories The End Point Of Marketing Theory Evolution?
}

Catherine Sutton-Brady, University of Sydney, Australia Ranjit Voola, University of Sydney, Australia Ulku Yuksel, University of Sydney, Australia

\begin{abstract}
This paper is an exploratory literature review of western management and marketing philosophies which are increasingly dominating the theory and practice across the world. Applying Fukuyama's argument that western liberal democracy is the end point of political history to management and marketing philosophies, this paper examines whether western marketing and management theories are the final outcome of marketing and management evolution that can be universally accepted and practiced. A review of the current literature relating to the globalization debate suggests that globalization recognizes both the differences and the similarities in countries that should be taken into account in appropriately approaching business across borders. Since developing countries have differing socio-economic and cultural backgrounds, this reality provides a justification for investigating whether western marketing and management philosophies are deemed appropriate in the context of developing countries. An examination of the trends in developing countries, such as India and China, in the development and application of indigenous management theories provides a basis for arguing that western marketing and management philosophies may not be the final point of marketing and management evolution in some developing countries. Several research questions are raised in this paper for further exploration and it aims to stimulate debate on the current state of marketing theory evolution.
\end{abstract}

Keywords: Marketing theory, Fukuyama, globalization, developing countries

\section{INTRODUCTION}

$\mathcal{G}^{\prime}$ n a seminal book titled "The End of History and the Last Man", Fukuyama (1992), a political scientist, strongly argues that history has reached its final stage in the context of political governance. Fukuyama develops this argument by reviving the Hegelian notion that there is a "direction" to history. For example, Karl Marx argued that the path of historical development had a purpose and would only end with the achievement of a communist utopia, suggesting that history has a beginning, middle and an end. Applying this Hegelian notion, Fukuyama (1992) asserts that the direction of the history ultimately runs toward liberal democracy and capitalism. Fukuyama suggests that liberal democracy may constitute the end point of human ideological evolution, and therefore, this is the final form of human government that all societies are currently approaching. The evidence he provides is that there is no viable alternative to western liberalism (i.e., fall of communism). This paper applies the Hegelian notion of history and Fukuyama's philosophical notion of the end of history thesis in the context of liberal democracy to management and marketing philosophies and examines whether these philosophies are the final point of management and marketing evolution. Specifically, the paper asks the question, "Are there no viable alternative to western management and marketing philosophies?"

An examination of these issues is pertinent for three reasons. Firstly, dominant theoretical frameworks, primarily shaped and developed by western scholars, are likely to shape cognitive orientations and eventually affect marketing practice (Dacin et al. 2002). For example, McCarthy's (1960) marketing mix, Kotler and Levy’s (1969) 
application of marketing in the non-profit context, and Kohli and Jaworski's (1990) investigation of market orientation were developed by academics in American universities. Its affect on shaping marketing thought and practice is clearly evident. Secondly, Steenkamp (2005) urges marketing researchers to move out of the "U.S. silo" for several reasons: (1) conducting international research allows for cross-national generalizability and investigating contingencies in marketing theory and (2) it pushes the theoretical envelope by including country characteristics as moderators of the structural relations between the constructs in the theories. Thirdly, there has been a trend in developing countries, specifically India, Russia and China, toward mass adoption of western management philosophy (Bensahel and Chamsoutdinova-Stieven, 2008; Thomas and Philip 1994; Tan and Khoo 2002) without a robust debate about the appropriateness of this adoption. This adoption can be attributed to such developments as, increased free trade and integration (Floyd, 1999) and the rapid progress of western economies (Gopinath 1998).

Developing countries, such as Brazil, Russia, India and China (BRIC's), have been and are likely to increasingly influence the growth in world trade as they have the greatest potential for multinational companies (The Economist, 2008; Panigrahi, Ede and Calcich 2002). Consequently, understanding the underlying nature of the relevant issues involved in doing business in these countries is increasingly becoming a priority for multinationals. An important question facing multinationals, while planning to conduct business in India and China, is whether their management/marketing theories, primarily based on western ideology, are appropriate in a developing country context.

To this end, this paper firstly discusses the phenomenon of globalization. A discussion of globalization sets the foundation for investigating whether western management philosophy is the final point of management evolution that is being approached globally. Lastly, a discussion of indigenous management philosophies in India and China is undertaken to provide answers to the question, "Are there no viable alternatives to western management and marketing philosophies?" It is pertinent to highlight that philosophy can be viewed "... as any practice that makes new objects appear for knowledge or old objects appear in a radically new light" (Tadajewsi 2005 p. 662). This paper views philosophy as the former since the globalization debate has been a key theme of investigation for many years in both management and marketing.

\section{GLOBALIZATION}

Globalization, which can be viewed as global consumer convergence, homogenized markets, one world, and MacWorld (Anwar 2007), reflects a business orientation based on the belief that the world is becoming more homogeneous and that distinctions between national markets are not only fading but, for some products, will eventually disappear (Czinkota and Ronkainen 2004). The underlying principle of globalization is that consumer preferences and requirements are similar across countries (Johansson 2003). Consequently, globalization requires a certain degree of uniformity in product, services, pricing, distribution, and promotion across country markets. Therefore, global products are usually standardized with some uniform features in different foreign countries (Czinkota and Ronkainen 2004; Johansson 2003). In fact, globalization is a process of replication for many multinationals in which they see this process as an efficient usage of strategies, and even as a way of achieving savings. These savings are achieved through the emergence of economies of scale and scope which reveal when multinationals are able to spread one successful business model as widely as possible across many (in fact, almost all) countries (Ghemawat 2003). Hence, the only demanding decision multinationals have to make would be how much to standardize and how much to modify to local tastes. However, this very decision in focusing entirely on how much to standardize and how much to adapt is the largest mistake which multinationals make, as it hinders multinationals from seeing the differences rather than the similarities. By doing so, Ghemawat (2003) argues that multinationals fail to see many market opportunities. He calls this phenomenon arbitrage; i.e, being smart enough to utilize from the differences rather than the similarities. ${ }^{1}$

\footnotetext{
${ }^{1}$ In economics, arbitrage is the practice of taking advantage of a price differential between two or more markets where this imbalance emerged from the difference between the several markets' prices breed a profit. When used by academics, an arbitrage is a transaction that involves no negative cash flow at any probabilistic or temporal state and a positive cash flow in at least one state; in simple terms, a risk-free profit.
} 
In the management and marketing area, the debate about globalization was intensified by those who argued that multinationals should use one single strategy, regardless of the differences among nations, thus focusing on the similarities across international markets. However, national values, for example, affect the strategic aims, the content and the process of the followed strategy (Harris and Ghauri 2000). Thus, most observers today believe that this argument has failed and Levitt's predictions have not been proven true without noticing that Levitt, in fact, meant interaction that changes things rather than leaving things unaffected (Abdelal and Tedlow 2003). There is a wide array of writers taking opposing views on globalization and a wide-ranging collection of publications covering both sides; i.e., pro and anti-globalization, and it is a controversial debate (Anwar 2007). Pro-globalization writers emphasize the advantages of free trade and global integration (Bhagwati 2004) by stressing the factors which caused and made globalization unavoidable (Friedman 2005), intricacies of global economic integration, and world trade (Wolf 2004) benefits of liberal globalization and open markets (Wolf 2004) and how to spread a better globalization (Legrain 2004). Even Stiglitz (2002), who seems to have an anti-globalization view, is not criticizing globalization itself, but its mechanics and processes, particularly policies of multilateral institutions and unfair trade laws.

However, globalization did not emerge without rationale. There were numerous drivers effecting the surfacing of globalization at the firm level. These drivers are: 1) market-driven, such as common consumer needs that lead to the evolution of global consumers, distribution and logistics firms providing transportation and storage around the world generating global channels, and the recognition of the transferability of marketing ideas; 2) competition-driven, such as when firms followed their competitors who go global for two reasons - to increase revenue and succeed, as well as to survive; 3) very significantly, cost-driven factors affecting the emergence of globalization, including economies of scale and scope, and sourcing advantages to help firms avoid unnecessary duplication of redesign products and promotional campaigns; and 4) technology drivers, such as the Internet, and government drivers made global expansion both possible and desirable for multinational firms. These drivers of going global also initiated the advantages of going global and having standardized products. The advantages of standardization are cost reduction, improved quality, enhanced consumer preference, global consumers, and global segments (Johansson 2003).

However, standardization, as a result of globalization, is not without its drawbacks at the firm level for several reasons. Firstly, firms may go off-target; i.e., they may miss the exact target in any one country. Secondly, standardization may cause lack of uniqueness since it fails to recognize customization and exclusivity. Especially in mature and affluent markets/segments, luxury becomes important and uniqueness is interpreted as indulgence. Thirdly, standardization requires open trade regimes and is threatened by protection of other countries via trade barriers. Finally, local competitors are familiar with local traditions and local consumer preferences which make them more capable in managing a defense strategy (Johansson 2003). As a result, the pitfalls of global standardization may be insufficient market research, over standardization, poor follow-up, narrow vision, and inflexible implementation of the management strategy in headquarters (Johansson 2003).

Globalization has progressed throughout history in an unbalanced fashion in terms of speed and amount. After the world experienced almost 50 years of regression, economic and cultural globalization started to escalate, which saw national economies merge into a single and standardized marketplace via commercial activities, including trade, technology, finance, marketing, production, and logistics. However, this pace and intensity of globalization provoked rapid consequences in the form of a serious debate on its economic, social, cultural, political, and technological affects on different nationalities.

The adaptation processes, including an acception or rejection of globalization by different nations' dissimilar managerial and philosophical application systems instigate deep consideration about the continuing capacity of globalization. This would include whether standardization of management and marketing functions would be feasible in culture-bound industries (Martenson 1987), whether international trade and investment is still regional (Rugman 2001), and whether most large multinationals having an average of $80 \%$ of total sales in their home regions should be considered global, with the exception of nine out of the largest 500 firms (the Fortune 500 who are clearly global), as very few multinationals are able to sell standardized products across nations (Rugman and Verbeke 2004). 
Previous research suggests that those who oppose globalization support the local as an alternative to the global. However, Ritzer (2003) argues that this effort would fail due to the progressive disappearance of the truly local. Even though one may agree with this view, to some extent, in regard of production, engineering, and marketing of products across nations, can one really argue that managerial practices should be or could be global? In terms of management, this would mean using the same management phenomenon and processes across nations, whereas it is obvious that each nation has its own managerial system that functions extremely well within the country's boundaries. So, the debate is whether to change a successful strategy for the sake of globalization and if it is possible to change it, as it is based on hundreds of years of tradition and culture.

Having discussed globalization, the next section investigates whether other countries, specifically India and China, are practicing indigenously developed theories.

\section{BUSINESS PHILOSOPHY IN THE ASIA-PACIFIC REGION}

It is naïve to think that all marketing and management theory is based on the western way. It is clear, in looking at other countries, that often their philosophy for doing business has it roots in ancient theories. This section will examine some of those indigenous theories. In particular, Indian and Chinese marketing and management philosophies will be examined in light of their standing as the fastest developing economies and their important place in the Asia-Pacific region.

Contemporary India is undergoing a transformation in business management based on market theory founded on western economic philosophy of capitalism (Chatterjee and Pearson, 2000). However, some Indian authors, such as Gopinath (1998), argue in favour of developing a locally-based theory of management that suits the unique needs of Indian business people interested in exploring the possibility of developing an indigenous theory of management founded on the rich Indian cultural heritage based on the evolutionary process of two thousand years. For example, a recent trend in building local business practices has been to look at ancient Hindu scriptures, such as Kautilya's Arthasastra that dates back to 300BC, which includes areas of economics and statecraft (Subramaniam, 1990). Furthermore, Srinivasan (2007) applies the principles laid out in a Tamil Veda, Tirukural, which is an exploration on the art of living, to business situations whilst Kanji (2003) applies Vendanta Philosophy of Karam, Bhakti and Janana to Leadership.

There has also been a search for identifying management concepts from Hindu religious texts (Simha 1994). Beer (1994) suggests that the Bhagavat Giva (900BC) allows for a holistic approach for management by highlighting such issues as the need for duty as the main motivating factor, rather than the need for actions. Bhagavat Gita is the most influential for management at the interfaces between business and society, culture of work, leadership, and self-management. In another example, Chakraborthy (1991) derived normative values from the ancient Buddhist and Hindu text, Gandhi, Tagore and Vivekananda. Focusing primarily on Indian religious and cultural values, Chakraborthy (1991) proposed that his model provided an alternative path for some thoughts on the peculiarity of Indian culture having implication for Indian management practices. The main focus of Chakraborthy's model is on the quality of the human mind and its implications on emotions that one can hold. This implies a superimposition of norms and values on skill and not necessarily vice versa. This prior discussion is important because an increasing number of senior Indian managers are already following the management philosophy based on these scriptures (Katiyar and Rekhi 1994).

An interesting development in recent years has been that the big businesses in western countries are applying Indian philosophy to management. For example, in a recent article in Business Week, the following question is asked: "Has the the Bhagavad Gita replaced The Art of War as the hip new ancient Eastern Management Text?" Phrases from the Bhagavad Gita are increasingly being used on company and consultant websites. Prahalad, a management guru at the University of Michigan, argues that there is a trend toward a more holistic business; that is, a stakeholder-driven approach, as opposed to a shareholder driven agenda, that currently characterises business. Business Week terms this the Karma Capitalism (Business Week, 2006). In the specific context of marketing, there is a relationship between Indian philosophy and current marketing theory in that current marketing theory has moved away from exploiting or manipulating consumers to collaboration, which has been emphasised in the Bhagavad Gita. 
We also see similar patterns in China. Much has been written about the role of Guanxi and Mianzi in Chinese business and the impact it has for westerners doing business in China (Alston, 1989; Buckley et al 2006; Hutchings and Weir, 2006; Luo, 1997). Perhaps the major difference between Western and Chinese thought is the fact that Western thought is said to be based on categorization, while Chinese thought is integrative and all encompassing in nature. As a result of this approach, the Chinese don't break things into parts as Westerners would do, but they look at all things in terms of relationships, be they social, economic or biological, and look at those relationships in totality (Chen 2002). From this flows the concept of guanxi, which is considered an inseparable part of the Chinese business environment (Buckley et al 2006). Guanxi refers to the idea of drawing on connections in order to secure favours (Yuo 1997). It is reciprocal in nature, so if I do you a favour, there is an obligation that at some point you will return the favour. It is also intangible as there is, in effect, an unspoken commitment overtime in all guanxi relationships (Yuo 1997).

Guanxi has its roots in Confucianism from over 2,000 years ago. Confucianism attempts to establish a "social hierarchy strong enough to harmonise a large and complex society of contentious human beings" (Yuo 1997). Interestingly, guanxi often favours the weaker party. An unequal exchange gives face to the more powerful party in that it gives them increased status in society (Alston, 1989). Face or Mianzi is another crucial aspect of doing business in China. It is imperative that the Chinese party does not lose face, so it is important to not only maintain good relationships through Guanxi, but also to ensure that the Chinese person's mianzi is protected at all times. Mianzi is linked to your prestige and standing in society. Loss of mianzi often leads to loss of guanxi and indeed, if you do not have good mianzi, it is impossible to foster good guanxi relationships. Losing mianzi is considered equivalent to the physical mutilation of one's eyes, nose or mouth (Yuo 1997).

As mentioned, the concepts of guanxi and mianzi are deeply rooted in ancient Chinese philosophy. Indeed the philosophies of all influential Chinese thinkers - Confucius, Lao Tzu and Sun Tzu- pervade Chinese culture (Chen 2002) and as a result, their business practices and marketing and management theories. In addition to these Chinese philosophers, shaping Chinese thought on acquiescence to authority and the group orientation is the institutionalised culture of fear from the time of Mao's Cultural Revolution, a tradition reinforced by Marxist Leninist-Maoism (Hutchings and Weir 2006).

So while it is clear and acknowledged by some authors that the prevalence of the use of the English language has popularised western management thinking throughout the world, there is evidence that much of the management and marketing practises in China are still very much based on indigenous philosophies. Indeed, it is often thought that eastern beliefs and philosophies are not so easily transplanted to other countries because of the constraints of the Chinese language (Pheng 1995). Many believe that to fully understand the Chinese philosophies means to look to the past and attempt to understand the works of the pre-eminent Chinese thinkers historically.

The ancient works of Confucius and Lao Tzu are still considered to be what shapes Chinese culture, and all three hold similar and overlapping views. Lao Tzu wrote the Tao Te Ching in the $5^{\text {th }}$ or $6^{\text {th }}$ century BC (Hensler et al 2000). Lao Tzu was a contemporary of Confucius and his philosophy concentrates on tranquillity. There are many similarities between the teachings of Confucius and Taoism. Tao is a way of life that is quite simply about living effortlessly and correctly and in harmony with others. Tao follows the laws of nature and therefore benefits everyone (Davis 2004). It is about being gracious and non-competitive. Confucism and Taoism are understood to run in harmony throughout Chinese life (Pheng 1995). They are the basic underpinning of Guanxi and Mianzi. Sun Tzu's military classic "Art of War" is another medium for understanding many of China's business practises today. Sun Tzu is considered the model for strategic thinking in China (Pang et al 1998). It is strongly based on time and patience, two concepts which result in many differences between East and West. Again, the Tao and Confucius teachings can be seen to have influence here as well. There is also a great emphasis on flexibility:

"Just as water shapes itself according to the ground, an army should manage its victory in accordance with the situation of the enemy. Just as water has no constant shape, so in warfare there are no fixed rules and regulations....therefore do not repeat the tactics that won you a victory, but vary them according to the circumstances (Sun Tzu, quoted in Pang et al 1998). 
It is obvious that to do business in India and China requires an understanding, however basic, of the underlying philosophies. While it is not the aim of this paper to compare the differing eastern and western philosophies, we are seeing a trend where western philosophy of business is drawing on the eastern philosophies. There is a considerable body of research looking at relationship development and network building which, while not overtly, clearly builds on the notion of guanxi and mianzi. The west is clearly learning from the collective approach of the Chinese and perhaps the most important thing is that despite globalization, the way of doing business in China and India continues to be based predominantly on indigenous philosophies that have clearly stood the test of time.

\section{FUTURE RESEARCH AND CONCLUSIONS}

This paper applied Fukuyama's argument that western liberal democracy is the final point of governance to management and marketing theories and asks two questions: 1) "Is western marketing and management really the end of marketing and management theory evolution?" and 2) "Are there no viable indigenously developed theories?" The prior discussion suggests that, although there is a clear trend toward the adoption of western management theory, there are efforts in both countries to develop and apply indigenously developed theories. Therefore, the answers to the above questions, in the context of India and China, remain debatable. George Orwell, in his satire on communism, Animal Farm, summarizes communism by the phrase, "all are equal, but some are more equal than others". Globalization thus far has been dominated by western ideas and theories; therefore, the fundamental argument of globalization of the interdependence of countries, in reality, has been the dependence of developing countries on developed countries. However, as the affect of fall in the stock market in Shanghai, China (March, 2007) which wiped out USD 1.5 trillion of world stock market, illustrates the growing dependence of developed countries on developing countries (trend toward real interdependence). Transferring this argument to marketing theories, it is arguably the case that some key theoretical concepts, such as relationship marketing, are being influenced by Guanxi, a Chinese concept. Therefore, not only are developing countries practicing indigenous marketing theory, but are influencing and shaping western marketing theories. More recently, however, evidence suggests that the old adage 'if the U.S economy sneezes, the whole world gets a cold' has some credence with the credit-crunch affecting economies around the globe (Gilbert, 2008).

The references made to the current thought on the issue are still developing, especially in the context of the developing nations. As the current debate progresses, it is expected that some of the controversial issues will be resolved through increasing participation of the pundits representing a wide range of cultures, especially the developing world. Furthermore, in order to clearly answer the question, there are several other issues that need further exploration and understanding. Firstly, do other developing countries have similar views of exploring their own indigenous marketing and management theories? Secondly, how effective are those strategies based on indigenous management theories? Thirdly, Chatterjee and Pearson (2000), suggest that a mixture of indigenous and western debate of applicability of western theories into the developing countries gives rise to a notion of a mix of western and indigenous management theories that might be appropriate for developing countries.

\section{AUTHOR INFORMATION}

Catherine Sutton-Brady is a senior lecturer in marketing in the Faculty of Economics and Business at the University of Sydney. She holds an MBS from University College Cork, Ireland and was awarded her PhD from the University of Western Sydney, Australia. Her research interests lie in the area of international marketing, business to business marketing and marketing education. She has published articles in Journal of Business Research, Journal of Marketing Education, Assessment and Evaluation in Higher Education, and other journals.

Ranjit Voola is a senior lecturer in marketing in the Faculty of Economics and Business at the University of Sydney. He obtained a $\mathrm{PhD}$ from the University of Newcastle, Australia. His research revolves around strategic marketing and international marketing. He has published in Journal of Knowledge Management, Strategic Change and Journal of Marketing Education.

Ulku Yuksel is a Lecturer in Marketing at The University of Sydney, Faculty of Economics and Business. Her research interests revolve around culture and international marketing. 


\section{REFERENCES}

1. Abdelal, R. and Tedlow, R. S. (2003), "Theodore Levitt's 'The Globalization of Markets': An Evaluation after Two Decades". Harvard NOM Working Paper No. 03-20; Harvard Business School Working Paper No. 03-082.

2. Alston, Jon P. (1989) "Wa, Guanxi and Inhwa: Managerial principles, in Japan, China and Korea" Business Horizons, March-April pp. 26-31.

3. Anwar, Syed T. (2007), "Global Business and Globalization,” Journal of International Management, Article in Press, 13.

4. $\quad$ Beer, S. (1994) "May the Whole Earth be Happy: Loka Samastat Sukhino Bhavantu”, Interfaces, Vol. 24., No. 4, pp. 83-93.

5. Bensahel, P.and Chamsoutdinova-Stieven, T. (2008), "The adaptation of western management methodology to the investigation of personnel management practices in Russia, Innovations 2008/1, no. 1, pp. $87-107$

6. $\quad$ Bhagwati, Jagdish (2004), In Defence of Globalization, Oxford University Press, New York.

7. Blunt, P. and Jones M. L. (1997), "Exploring the Limits of Western leadership theory in East Asia and Afria", Personnel Review, Vol. 26., No. 1. pp: 6 - p23

8. Buckley, Peter J., Clegg, Jeremy and Tan, Hui (2006) "Cultural awareness in knowledge transfer to ChinaThe role of guanxi and mianxi” Journal of World Business, No. 41 pp.275-288.

9. $\quad$ Business Week, (2006), Karma Capatalism, October, $20^{\text {th }}, 2006$

10. Chakraborty, S. K. (1991), Management by Values, Bombay: Oxford University Press.

11. Champy, J., 1997, “Think globally, sell locally”, Sales \& Marketing Management, pp. 24-5

12. Chatterjee, S.R. And Pearson, A. L. (2000), "Indian Managers in Transition: Orientations, Work Goals, Values and Ethics", Management International Review, Vol. 40, No. 1, pp. 81-95

13. Chatterjee, S.R. and Pearson, C.A.L. (2000), "Work Goals and Societal Value Orientation of Senior Indian Managers: An Empirical Analysis" Journal of Management Development, Vol. 19, No. 7, pp. 643-653.

14. Chen, Ming-Jer (2002) "Transcending paradox: The Chinese "middle way" perspective" Asia Pacific journal of Management, Vol. 19 Iss. 2,3, p. 179.

15. Czinkota, M.R. and Ronkainen, I.A. (2004), International Marketing, $7^{\text {th }}$ edition, Thomson, Mason, Ohio

16. Daft, D., 2000, "Back to classic Coke", The Financial Times, p. 20.

17. Dahringer, L.D., Mühlbacher, H., 1991, International Marketing: A Global Perspective, Addison - Wesley Publishing Company, Reading, MA.

18. Davis, Donald D. (2004) “The Tao of leadership in virtual teams" Organizational Dynamics, Vol. 33, No. 1, pp. 47-62.

19. Elenkov, D.S. (1998), “Can American Management Concepts Work in Russia? A cross- cultural Comparative Study”, California Management Review, Vol. 40, No. 4, pp. 133-156.

20. Floyd, D. (1999), “ Eastern and Western Management Practices: Myth or Reality?” Management Decision, Vol. 37., No. 8, pp. 628-632.

21. Friedman, Thomas, L. (2005), The World is Flat: A Brief History of the Twenty-First Century, Farrar, Straus and Giroux, New York.

22. Fukuyama, F. (1982), The end of History and The Last Man. New York: Penquin.

23. Ghemawat, P (2003), The Forgotten Strategy, Harvard Business Review, Vol. 81 (11), pp. 76-84.

24. Ghoshal, S., (1987), "Global Strategy: an Organizing Framework", Strategic Management Journal, Vol. 8, pp. $425-40$.

25. Gilbert, M. (2008), Credit Crunch Far from over, Sydney Morning Herald, August $21^{\text {st }}$, 2008, available at: http://business.smh.com.au/business/credit-crunch-is-far-from-over-20080821-3zh4.html

26. Gopalan, S., and Stahl, A. (1998), "Application of American Management Theory and Practices to the Indian Business Environment: Understanding the Impact of National Culture", American Business Review, June, pp. 30-41.

27. Gopinath, C (1998), "Alternative Approaches To Indigenous Management In India", Management International Review. Third Quarter, Vol. 38. No. 3, pp. $257-275$.

28. Harris, S. and Ghauri, P. (2000), "Strategy formation by business leaders: exploring the influence of national; values," Eurpean Journal of Marketing, Vol.34 (1/2), pp.126-. 
29. Hensler, Douglas A., Edgeman, Rick L. and Guerrero-Cusumano, Jose-Luis (2000) "East meets West: weaving the threads of Deming, Da Vinci and the Tao Te Ching" Total Quality Management, Vol. Nos. 4,5,\&6 pp. 501-508.

30. Hutchings, Kate and Weir, David (2006) "Guanxi and Wasta: A Comparison” Thunderbird International Business Review, Vol . 48(1) pp.141-156.

31. Jaeger, A.M and Kanungo, R. N. (1991) Management in Developing Countries. New York: Routledge, Chapman, and Hall.

32. Johansson, J.K. (2000), Global Marketing: Foreign Entry, Local Marketing \& Global Management, Irwin McGraw - Hill Companies, Boston, MA.

33. Johansson, J.K. (2003), Global marketing, $3^{\text {rd }}$ edition, McGraw-Hill, NY, NY

34. Kanji, G. (2003), "A new business excellence model from an old Indian philosophy", Total Quality Management \& Business Excellence", Vol. 14. pp. 1071-1076.

35. Katiyar, A. and Rekhi, S. (1994), "Guiding Principles”, India Today, 15 July, pp. 110-111

36. Keegan, W.J., Green, M.S. (2000), Global Marketing, Prentice-Hall, Upper Saddle River, NJ.

37. Kohli, A.K. and Jaworski, B.J. (1990) 'Market Orientation: The Construct, Research Propositions, and Management Implications', Journal of Marketing 54 (April): 1-18.

38. Kotabe, M., Helsen, K. (1998), Global Marketing Management, John Wiley \& Sons.

39. Kotler, P. and Levy, S.J. (1969) 'Broadening the Concept of Marketing', Journal of Marketing 33 (January): 10-15.

40. Legrain, Philippe (2004), Open World: The Truth About Globalization, , Ivan R. Dee, Chicago, Illinois.

41. Levitt, T. (1983), The globalization of markets," Harvard Business Review, (May-June) 61 (3), $92-102$.

42. Luo, Yadong (1997) "Guanxi: principles: philosophies and implications" Human Systems Management, No. 16 pp.43-51.

43. Martenson, R. 1987, "Is standardisation of marketing is feasible in culture-bound industries? A European case study," International Marketing Review, (Autumn), 7-17.

44. Mattews, V.E. (2000), "Management in a Developing Nation: And We Thought American Managers had it Tough!” Multinational Business Review, Vol. 8, No. 2, pp. 10-16.

45. McCarthy, E.J. (1960) Basic Marketing: A Managerial Approach. Homewood, IL: Richard D. Irwin.

46. McFarland, D. E. (1986), The Managerial Imperative, Massachusetts: Ballinger.

47. Mesdag, M.V. (2000), "Culture-sensitive adaptation or global standardization-duration-of-usage hypothesis," International Marketing Review, 17 (1), 74-

48. Middleton, K.L., and Jones, J.L. (2000), "Socially Desirable Response Sets: The Impact of Country Culture", Psychology and Marketing, Vol.17, No. 2, pp. 149-163.

49. Newman, K.L. and Nollen, S.D. (1996), "Culture and Congruence: The Fit Between Management Practices and National Culture”, Vol. 3., No.2. Journal of International Business Studies, Fourth Quarter, pp. 753799.

50. Pang, Chee Keen, Roberts, Diane and Sutton, John (1988) "Doing Business in China" International Journal of Contemporary Hospitality Management, Vol. 10 Iss. 7, p. 272.

51. Panigrahi, B., Ede, F.O. and Calcich, S. (2002), “American Executives” Perceptions of the Business Climate of the Two Emerging Markets of India and China”, Asia Pacific Journal of Marketing and Logistics, Vol. 14. No. 1. pp. 40- 58.

52. Pheng, Low Sui (1995) "lao Tzu's Tao Te Ching and its relevance to project leadership in construction" International Journal of Project Management, Vol. 13 No. 5, pp. 295-302.

53. Ritzer, G. (2003), "The globalization of nothing," SAIS Review, 23 (2), 189-200.

54. Rugman, A.M. (2001) The End of Globalization: What it Means for Business, Random House, New York.

55. Rugman, A.M. and Verbeke, A. (2004), “A perspective on regional and global strategies of multinational enterprises," Journal of International Business Studies, 35, 3-8.

56. Samiee, S., Roth, K. (1992), “The Influence of Global Marketing Standardization on Performance”, Journal of Marketing, Vol. 56, pp. 1-17.

57. Sheth, J.N. and Parvatiyar, A. (2001), "The Antecedents and consequences of Integrated Global Marketing", International Marketing Review, Vol. 18, No. 1, pp. 16-29.

58. $\quad$ Simha, S. L. N., Management With Dharma all the Way, 1994.

59. Srinivasan, V. (2007), New Age Management Philosophy from Ancient Indian Wisdom, Roli Books: New Delhi, India. 
60. Steemkamp, (J), 2005, Moving out of the U.S. Silo: A call to arms for conducting international marketing research, Journal of Marketing, Vol, 69, pp. 1-25.

61. Stiglitz, Joesph E. (2002), Globalization and its Discontents, W. W. Norton and Company, New York.

62. Svensson, G. (2002), Beyond Global marketing and the Globalization of Marketing Activities", Management Decision, Vol. 40, No. 6. pp. $574-583$

63. Tadjeski, M. (2005), “The philosophy of Branding, Journal of Marketing Management, Vol. 21, No. 5/6, pp. 659-663.

64. The Economist, (2008), The New Champions; Emerging markets are producing examples of capitalism at its best, September, $18^{\text {th }}, 2008$, available at http://www.economist.com/specialreports/displaystory.cfm?story id=12080711

65. Wolf, Martin, (2004), Why Globalization Works, Yale University Press, New Haven, CT. 
NOTES 